\title{
Comparative Study on the ALA Photodynamic Effects of Human Glioma and Meningioma Cells
}

\author{
Jui-Chang Tsai, MD, PhD, ${ }^{1,2 *}$ Yi-Yun Hsiao, Ms, ${ }^{1}$ Lee-Jene Teng, Ms, ${ }^{3}$ \\ Chin-Tin Chen, PhD, ${ }^{1}$ and Ming-Chien Kao, MD, DMSc ${ }^{2}$ \\ ${ }^{1}$ Laser Medicine Research Center, College of Medicine, National Taiwan University, \\ Taipei 100, Taiwan \\ ${ }^{2}$ Department of Surgery (Neurosurgery), College of Medicine, National Taiwan \\ University, Taipei 100, Taiwan \\ ${ }^{3}$ Medical Technology, College of Medicine, National Taiwan University, \\ Taipei 100, Taiwan
}

Background and Objective: The purpose of this study was to compare the differential susceptibility to photodynamic therapy (PDT) mediated damage in human U-105MG glioma cells and $\mathrm{CH}-157 \mathrm{MN}$ meningioma cells in vitro using 5 -aminolevulinic acid (ALA) as photosensitizer, and to determine if growth factors would enhance PDT-mediated damage of these cells.

Study Design/Materials and Methods: U-105MG or CH-157MN cells were irradiated with polychromatic light in the presence of ALA. A Xenon lamp (150 W) was used as the light source. For the study on the effect of growth factor on ALA-PDT, cells were cultured in serum free medium for 24 hours. Epidermal growth factor (EGF), basic fibroblast growth factor (bFGF), or platelet derived growth factor BB (PDGF-BB) was added to achieve a final concentration of $50 \mathrm{ng} / \mathrm{ml}$. 30 minutes later, cells were incubated with ALA (100 $\mathrm{mg} / \mathrm{ml})$ for 24 hours, washed, and irradiated with light $\left(11 \mathrm{~J} / \mathrm{cm}^{2}\right)$. MTT tetrazolium assays were performed 24 hours after light irradiation.

Results: The inhibition of metabolic cellular function in U-105MG cells by ALA depended on both light energy density and ALA concentration. The susceptibility to ALA-PDT was profoundly lower for CH-157MN meningioma cells than U-105MG glioma cells. When incubated with ALA $(100 \mu \mathrm{g} / \mathrm{ml})$, U-105MG cells exhibited an $L^{2} D_{50}$ around $8 \mathrm{~J} / \mathrm{cm}^{2}$ of light irradiation, whereas that of $\mathrm{CH}-157 \mathrm{MN}$ cells was more than $25 \mathrm{~J} / \mathrm{cm}^{2}$. EGF, bFGF, or PDGF-BB did not have any effects on the susceptibility of these two cell lines to ALA-PDT.

Conclusion: ALA-PDT was more effective in killing U-105MG glioma cells than $\mathrm{CH}-157 \mathrm{MN}$ meningioma cells. The differential susceptibility was likely due to differential accumulation of PpIX in these cells. EGF, bFGF, or PDGF-BB did not have stimulatory or inhibitory effect on the efficiency of ALA-PDT. Lasers

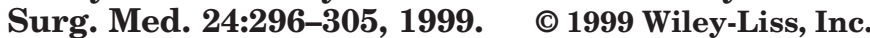

Key words: glioma; meningioma; epidermal growth factor; fibroblast growth factor; ALA; PDT

Contract grant sponsor: National Taiwan University Hospital; Contract grant number: Medical Research grant NTUH: S861007-A19.

*Correspondence to: Jui-Chang Tsai, M.D., Ph.D., Rm. 824, 8F, No. 7 Chung-Shan S. Rd., Taipei 100, Taiwan.

E-mail: jctsai@ha.mc.ntu.edu.tw

Accepted 5 January 1999

(C) 1999 Wiley-Liss, Inc. 


\section{INTRODUCTION}

Photodynamic therapy (PDT) consists of the administration and uptake of a photosensitizer in a tumor followed by irradiation with light of an appropriate wavelength to produce a cytotoxic effect at the site where the photosensitizer is situated. It has the potential to produce selective necrosis of tumors without causing damage to surrounding normal tissue based on the ability of photosensitizers to concentrate preferentially in malignant tissue [1]. The photosensitizers that have received the most extensive investigation both in the laboratory and clinically are hematoporphyrin derivative (HPD) and the more purified fraction Photofrin. However, their definitive active molecular component remains in doubt [2]. In addition, both sensitizers produced prolonged skin photosensitization. 5-amino-levulinic acid (ALA) is a precursor of protoporphyrin IX (PpIX) in heme biosynthesis, and endogenous PpIX produces effective photosensitization when activated by $630 \mathrm{~nm}$ light [3]. Administration of ALA bypasses the feedback control system in the heme biosynthetic pathway, resulting in cellular/tissue accumulation of photosensitizing amounts of PpIX. The potential usefulness of ALA for PDT of tumors has been demonstrated in animal $[3,4]$ and human studies [5-7]. The cutaneous photosensitivity with ALA in humans is less prolonged than with many other agents used in PDT [3].

It has been widely accepted that alterations in two types of genes, oncogenes, and tumor suppressor genes, contribute to tumorigenesis. Inappropriate expression of oncogenes can foster tumor development by stimulating cell proliferation. However, it is still not clear whether cells under active proliferation are more susceptible to PDT than the cells under stationary conditions.

In this study, we investigated the photodynamic effects of ALA in CH-157MN human meningioma cells and U-105MG human glioma cells and compared if there was any differences in the effectiveness of ALA-PDT between meningioma (the most common of benign brain tumors) and glioma (the most common of malignant brain tumors) cells. The aims of this study are:

(1) To investigate whether there is production and accumulation of PpIX by glioma cells and meningioma cells on exposure to ALA and whether this leads to a PDTinduced toxicity.

(2) To compare the rate of PpIX accumulation between these cell lines.
(3) To study and compare the effects of growth factors on the susceptibility to ALA-PDT in glioma cells and meningioma cells, that is, to understand if tumor cells are more susceptible to PDTinduced cytotoxicity when stimulated with growth factors.

\section{MATERIALS AND METHODS \\ Biochemical and Biological Reagents}

Dulbecco's modified Eagle's medium mixed 1:1 with Ham's nutrient mixture F-12 (DMEM/ F12; Sigma Chemical Co., Inc., St. Louis, MO) supplemented to $2 \mathrm{mM}$ with L-glutamine was used for cell cultures. Fetal bovine serum (FBS; Intergen, Purchase, NY) was heat inactivated $\left(56^{\circ} \mathrm{C}, 45\right.$ minutes). Epidermal growth factor (EGF) (human, recombinant, Promega, Madison, WI), recombinant human platelet derived growth factor (PDGF-BB) (R\&D systems, Minneapolis, $\mathrm{MN}$ ), and basic fibroblast growth factor (bFGF) (Promega, Madison, WI) were all diluted to specified concentrations in Dulbecco's phosphatebuffered saline (PBS, pH 7.2). Culture media and sera were determined to have $<100 \mathrm{pg} / \mathrm{ml}$ of endotoxin by the Limulus amoebocyte lysate assay.

Cell lines. The glioblastoma cell lines $\mathrm{U}-105 \mathrm{MG}$ and meningioma cell line $\mathrm{CH}-157 \mathrm{MN}$ were obtained from Dr. Yancey Gillespie, University of Alabama at Birmingham, Birmingham, Alabama. The U-105MG cell line is originally from Dr. Darell D. Bigner, Duke University, Durham, North Carolina, and has been described in detail [8]. The $\mathrm{CH}-157 \mathrm{MN}$ cell line was obtained from Dr. Gillespie, and is originated from Dr. M. S. Mahaley. This cell line was established in culture from a meningioma resected in 1977 from a 59-year-old woman. Both cell lines have been passed > 40 times and maintained in 150 $\mathrm{cm}^{2}$ plastic tissue culture flasks (Falcon Plastics, Lincoln Park, NJ) in complete culture media $(\mathrm{DMEM} / \mathrm{F} 12+2 \mathrm{mM}$ L-glutamine $+8 \% \mathrm{FBS})$ at $37^{\circ} \mathrm{C}$ and $7.5 \% \mathrm{CO}_{2}$.

\section{Photosensitizers and Light Source}

Five-aminolevulinic acid (ALA) was obtained from Sigma (Sigma Chemical Co., MO, USA). This substance, once taken up by cells, is metabolized into PpIX that represents the photosensitizing agent. ALA was diluted in medium and neutralized to $\mathrm{pH} 7.2$ with $\mathrm{NaOH}$ immediately before use. Irradiation was performed using a polychromatic light source (150 W, MC-961, Otsuka Electronics 
Co., LTD., Osaka, Japan). Light emitted by this Xenon lamp was filtered with 2A filter (sharp cut at $420 \mathrm{~nm}$ ). The incident power density measured was $47 \mathrm{~mW}$.

Irradiation protocol. To determine the efficacy of PDT, tumor cells were plated at 5,000 cells/well in flat bottom 96 -well microtiter plates in $200 \mu \mathrm{l}$ culture medium containing $5 \%$ fetal calf serum. At 24 hours after plating, supernatant was replaced with $200 \mu \mathrm{l}$ medium containing various concentrations of ALA $(1,10,100,1000 \mu \mathrm{g} /$ $\mathrm{ml})$. The culture plates were wrapped in aluminum foil to avoid light exposure. After 24 hour incubation with ALA, cells were washed once with PBS, and phenol-red free medium was added. The cells were then irradiated for 5-30 minutes with incident power density of $12.4 \mathrm{~mW} / \mathrm{cm}^{2}$. As controls, cell cultures not incubated with any photosensitizer were treated in the same way. Cell cultures incubated with various concentrations of ALA but without light irradiation were used as dark controls. There was no detectable thermal effect that occurred during irradiation of the cells. Experiments were done in quintuplicates. After another 24 or 48 hour incubation, MTT (3-[4,5Dimethylthiazol-2-yl]-2,5-diphenyltetrazolium bromide) assay was performed.

Cell survival using an MTT assay. We determined the cytotoxic effects of ALA-PDT on U-105MG glioma cells and CH-157MN meningioma cells using an MTT assay. This assay is based on the reduction of a water soluble tetrazolium salt (MTT) to a purple, insoluble formazan product by mitochondrial dehydrogenases present only in living, metabolically active cells. A sample of $150 \mu \mathrm{l}$ of MTT $(0.2 \mathrm{mg} / \mathrm{ml})$ in phosphatebuffered saline was added to each well of a 96-well plate. The cells were incubated for 4 hours (avoid light) to allow generation of the colored formazan product. The medium was then removed, $150 \mu l$ of $20 \%$ dimethyl sulphoxide (DMSO) was added to each well, mixed, and waited for another $15 \mathrm{~min}$ utes (for complete dissolution of the fromazan dye). The absorbances at $540 \mathrm{~nm}$ were read on a microplate reader (Bio-Tek Instruments Inc., Vermont, USA). Proliferation of cells in the presence of the photosensitizer was defined as $100 \%$. We subsequently determined the dose yielding a $50 \%$ decrease in cell proliferation $\left(\mathrm{LD}_{50}\right)$. Percentage cell survival and cytotoxicity were calculated from the following formulas:

Percentage cell survival $=$

$$
\left(\mathrm{Abs}_{\text {test }} / \mathrm{Abs}_{\text {control }}\right) \times 100
$$

Percentage cell cytotoxicity $=$

$$
\left[1-\left(\mathrm{Abs}_{\text {test }} / \mathrm{Abs}_{\text {control }}\right)\right] \times 100
$$

Cell survival was also determined by trypan blue exclusion test and viable cell counting.

\section{Analysis of Effects of Growth Factors on ALA-PDT}

To determine the effects of growth factors on ALA-PDT, tumor cells were plated at 5,000 cells/ well in flat bottom 96 -well microtiter plates in 200 $\mu l$ culture medium $(\mathrm{DMEM} / \mathrm{F} 12+0.5 \% \mathrm{FBS}+2$ $\mathrm{mM}$ L-glutamine) for 24 hours. Cells were then incubated in $200 \mu \mathrm{l}$ medium (DMEM/F12 + 0.5\% $\mathrm{FBS}+2 \mathrm{mM}$ L-glutamine) containing various concentrations of EGF (3.125-50 ng/ml), bFGF (3.125-50 ng/ml), or PDGF-BB (3.125-50 ng/ml). Freshly prepared ALA was added to a final concentration of $100 \mu \mathrm{g} / \mathrm{ml} 30$ minutes later. After incubation with ALA in the dark for 24 hours, cells were washed once with PBS, and phenol-red free medium was added. The cells were then irradiated with light for 5-30 minutes with an incident power density of $12.4 \mathrm{~mW} / \mathrm{cm}^{2}$. As controls, cell cultures not incubated with any photosensitizer were treated in the same way. Cell cultures incubated with various concentrations of ALA and/or growth factor but without light irradiation were used as dark controls. There was no detectable heating effect that occurred during irradiation of the cells. Experiments were done in quintuplicates. MTT assay was performed 24 hours after light irradiation.

PpIX concentrations in cells. Cells were incubated with ALA at concentration of $100 \mu \mathrm{g} /$ $\mathrm{ml}$. After an incubation time of $1,2,3,4,5,6,7$, 24, 48, and 72 hours, PpIX was extracted with DMSO and was identified using fluorescence emission spectra. Fluorescence excitationemission spectra were measured from each sample using an Aminco-Bowman series 2 spectrofluorometer (SLM Instruments, $150 \mathrm{~W}$ Xenon lamp, ABS-2, Urbana, IL) with excitation at 405 $\mathrm{nm}$.

\section{Statistical Analysis}

Data were analyzed using a computersupported statistical program (SigmaStat, version 2.0, Jandel Co., San Rafael, CA). A one way analysis of variance (ANOVA) was used to evaluate if there were any statistically significant differences between all the experiment groups including the control group. The $P$ value for one way ANOVA was set to 0.05 . If a difference in the 

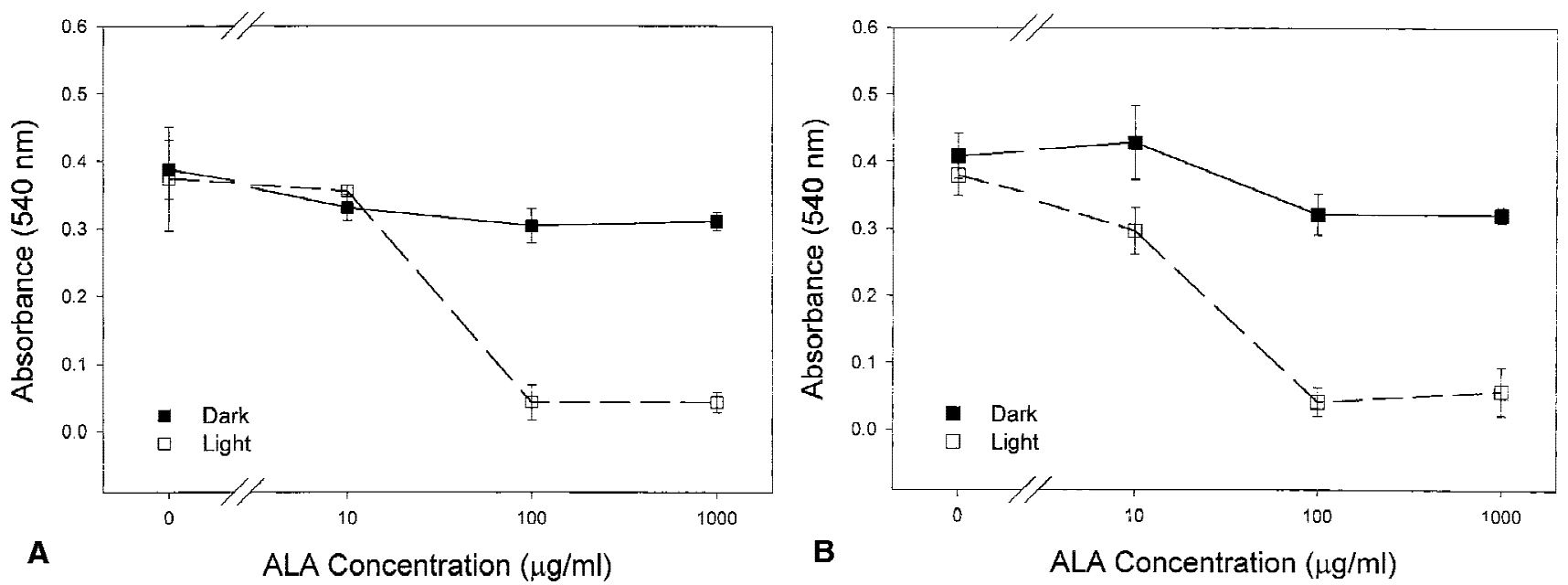

Fig. 1. U-105MG human glioma cells were plated, cultured in various concentrations of ALA (0-1,000 $\mu \mathrm{g} / \mathrm{ml})$ for $24 \mathrm{hours}$, washed out and irradiated with light $\left(12.4 \mathrm{~mW} / \mathrm{cm}^{2}\right)$ for 15 minutes $\left(11 \mathrm{~J} / \mathrm{cm}^{2}\right)$, and incubated for $24-48 \mathrm{hours}$. (A) MTT assay 24 hours after light treatment revealed obvious cell toxicity at ALA concentration above $100 \mu \mathrm{g} / \mathrm{ml}($ ANOVA, $P<0.01)$, dark control revealed slight cytotoxicity of ALA up to $1,000 \mu \mathrm{g} / \mathrm{ml}$. (B) MTT assay 48 hours after light treatment showed similar photodynamic effect. Dark control showed mild cytotoxicity of ALA alone above $100 \mu \mathrm{g} / \mathrm{ml}$. Each data point represents the mean \pm standard deviation of quintuplicate cultures.

groups was detected, a Bonferroni t-test was performed as the post hoc test (pairwise multiple comparison procedure). A three way ANOVA was used to evaluate if different experimental groups were affected by the three factors (growth factor, ALA, and light), which might interact. The $P$ value for three way ANOVA was set to 0.05. If a difference in the groups was detected, a Bonferroni t-test was performed as the post hoc test.

\section{RESULTS}

\section{Photodynamic Effects of ALA on U-105MG Glioma Cells}

The ability of PDT using ALA as photosensitizer to inhibit cell proliferation was initially tested on the glioma cell line U-105MG and meningioma cell line $\mathrm{CH}-157 \mathrm{MN}$. The photodynamic effects of ALA on U-105MG glioma cells depended on the concentrations of ALA (Fig. 1). Without light irradiation, ALA presented only mildly toxic to U-105MG glioma cells at concentrations above $100 \mu \mathrm{g} / \mathrm{ml}$ (a 24 hour incubation with ALA, detected with MTT either 24 or 48 hours after washout of the photosensitizer). In the presence of 10 $\mu \mathrm{g} / \mathrm{ml}$ ALA, however, a dose of $11 \mathrm{~J} / \mathrm{cm}^{2}$ light treatment was sufficient to produce a cytocidal effect which appeared at 48 hours after washout of the photosensitizer $(P<0.01$; one way ANOVA with Bonferroni multiple comparison procedure).

Both photosensitizer and light were required for an effective PDT (Fig. 2; ANOVA, $P=0.001$ ). Light irradiation alone did not show any cytotoxic effect, whereas ALA alone (with a concentration up to $100 \mu \mathrm{g} / \mathrm{ml}$ ) only showed a mild cytotoxic effect on U-105MG cells, and it was not statistically significant (ANOVA, $P>0.05$ ). However, in the presence of $100 \mu \mathrm{g} / \mathrm{ml}$ of ALA and $30 \mathrm{~J} / \mathrm{cm}^{2}$ light density, the cytotoxic effect became $89 \%$.

\section{Photodynamic Effects of ALA on CH-157MN Meningioma Cells}

The susceptibility to PDT was profoundly lower for $\mathrm{CH}-157 \mathrm{MN}$ meningioma cells compared to U-105MG glioma cells when ALA $(100 \mu \mathrm{g} / \mathrm{ml})$ was used as photosensitizer (Fig. 3A). The cytotoxicity was $25 \%$ in the presence of ALA $100 \mu \mathrm{g} /$ $\mathrm{ml}$ and light density of $35 \mathrm{~J} / \mathrm{cm}^{2}$ (Fig. 3B). No further increase of cytotoxicity could be obtained when light density was greater than $35 \mathrm{~J} / \mathrm{cm}^{2}$ (up to $100 \mathrm{~J} / \mathrm{cm}^{2}$ ). The $\mathrm{LD}_{50}$ of ALA-PDT for U-105MG glioma cells was around $8 \mathrm{~J} / \mathrm{cm}^{2}$ whereas that for $\mathrm{CH}-157 \mathrm{MN}$ was more than $100 \mathrm{~J} / \mathrm{cm}^{2}$ and could not be estimated. (Fig. 3B) Similar results were obtained using trypan blue exclusion test as readout (data not shown).

PpIX production in $\mathrm{CH}-157 \mathrm{MN}$ meningioma cells were much lower than those in U-105MG glioma cells. ALA is a precursor of PpIX in the biosynthetic pathway of heme. The administration of exogenous ALA induces accumulation of PpIX, which represents the fluores- 


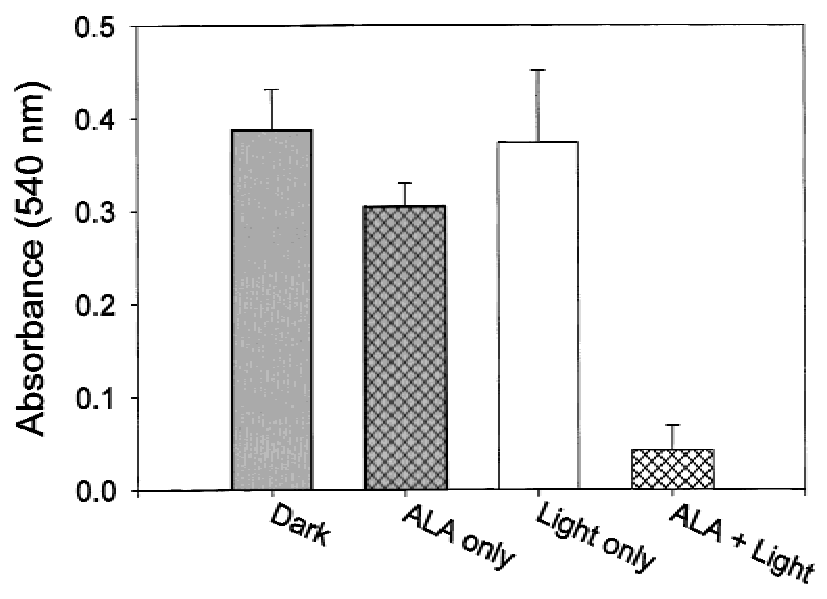

Fig. 2. Photodynamic effects of ALA on U-105MG human glioma cells. The cells were sensitized with ALA $(100 \mu \mathrm{g} / \mathrm{ml})$ for 24 hours and then irradiated with light $\left(11 \mathrm{~J} / \mathrm{cm}^{2}\right)$. Each data point represents the mean \pm standard deviation of nonuple cultures.

cent substance. The fluorescent intensity of PpIX in U-105MG glioma cells increased with time after the cells were incubated with ALA $(100 \mu \mathrm{g} / \mathrm{ml})$ and reached a plateau at 24 hours (Fig. 4). The plateau existed for at least 48 hours. The fluorescent intensity of PpIX in CH-157MN was very low compared to that of U-105MG cells (Fig. 4; note the different Y-axis scale in Fig. 4). It could be detected 4 hours after incubating with ALA (100 $\mu \mathrm{g} / \mathrm{ml})$, reached a plateau at 6 hours, but the intensity was very low. The plateau existed for 12 hours and then decreased gradually.

Susceptibility of U-105MG and CH$157 \mathrm{MN}$ to ALA-PDT was not altered when stimulated by EGF, bFGF, or PDGF-BB. Figure 5A shows that EGF $(50 \mathrm{ng} / \mathrm{ml})$ enhanced the growth of U-105MG cells by about $10 \%(P<$ 0.05; EGF vs. control). ALA $(100 \mu \mathrm{g} / \mathrm{ml})$ had mild toxicity to U-105MG cells $(P<0.05)$ whereas light $\left(11 \mathrm{~J} / \mathrm{cm}^{2}\right)$ alone did not have any effect. The combination of light and ALA had an augmented effect $(P<0.001)$ as was expected. EGF did not enhance or inhibit the efficacy of ALA-PDT toward U-105MG glioma cells $(P=0.244)$. A three way ANOVA was used to analyze the data and all pairwise multiple comparison procedures (Bonferroni t-test) were performed as the post hoc test. Similar results were obtained by using bFGF or PDGF-BB (Fig. 5B and 5C). Neither bFGF $(P=$ $0.174)$ nor PDGF-BB $(P=0.237)$ altered the susceptibility of U-105MG glioma cells to ALA-PDT.

Figure 6 shows that bFGF $(50 \mathrm{ng} / \mathrm{ml}$ ) enhanced the growth of CH-157MG cells by about $19 \%(P<0.05$; bFGF vs. control). ALA $(100 \mu \mathrm{g} / \mathrm{ml})$ alone had no toxicity to $\mathrm{CH}-157 \mathrm{MN}$ meningioma cells nor did light $\left(30 \mathrm{~J} / \mathrm{cm}^{2}\right)$ alone. The photodynamic effect of ALA on CH-157MN cells was not as good as that of U-105MG cells. Basic FGF did not alter the susceptibility of $\mathrm{CH}-157 \mathrm{MN}$ cells to ALA-PDT (Fig. 6). Neither EGF nor PDGF-BB had effects on the susceptibility of $\mathrm{CH}-157 \mathrm{MN}$ cells to ALA-PDT (data not shown).

The growth of $\mathrm{CH}-157 \mathrm{MN}$ meningioma cells was enhanced by bFGF in a dose dependent manner $(3.125$ to $50 \mathrm{ng} / \mathrm{ml})$ in the dark as is shown in Figure 7 (solid square). The efficiency of ALAPDT to CH-157MN cells was not altered by the presence of various concentrations of bFGF as shown in Figure 7, in which the two curves are nearly parallel to each other, showing no significant differences of cell survival rates (PDT group divided by dark control group at each concentration of bFGF) between groups of differential concentrations of bFGF (ANOVA, $P>0.05$ ).

\section{DISCUSSION}

\section{ALA-Mediated PDT is Effective for U-105MG Glioma Cells}

ALA is a precursor for the cellular biosynthesis of heme. There are two rate-limiting steps in this process: (1) synthesis of ALA from succinyl CoA and glycine by the enzyme ALA synthetase and (2) conversion of PpIX to heme by the enzyme ferrochelatase [9]. Administration of exogenous ALA bypasses the first rate-limiting step and enhances the biosynthesis of endogenous PpIX in certain types of cells and tissues and resulting in a buildup of PpIX which produces the photodynamic effect when it is photoactivated [2]. It has been demonstrated that certain neoplastic cells have reduced activity of the enzyme ferrochelatase $[10,11]$.

In this study, we showed that the inhibition of metabolic cellular function in U-105MG cells by PDT depended on both light energy density and ALA concentration. At the concentration $(100 \mu \mathrm{g} /$ $\mathrm{ml}$ of ALA) used in this PDT experiments, ALA itself was non-toxic to cells; similarly, the light energy density we employed (up to $15 \mathrm{~J} / \mathrm{cm}^{2}$ ) could not produce obvious detrimental effects on the cells studied. Light activation of ALA was necessary to elicit cell toxicity (Fig. 2).

The prognosis of patients with a high-grade cerebral glioma is very poor, for example, the median survival for glioblastomas multiforme is less than one year. Surgery provides a definitive his- 

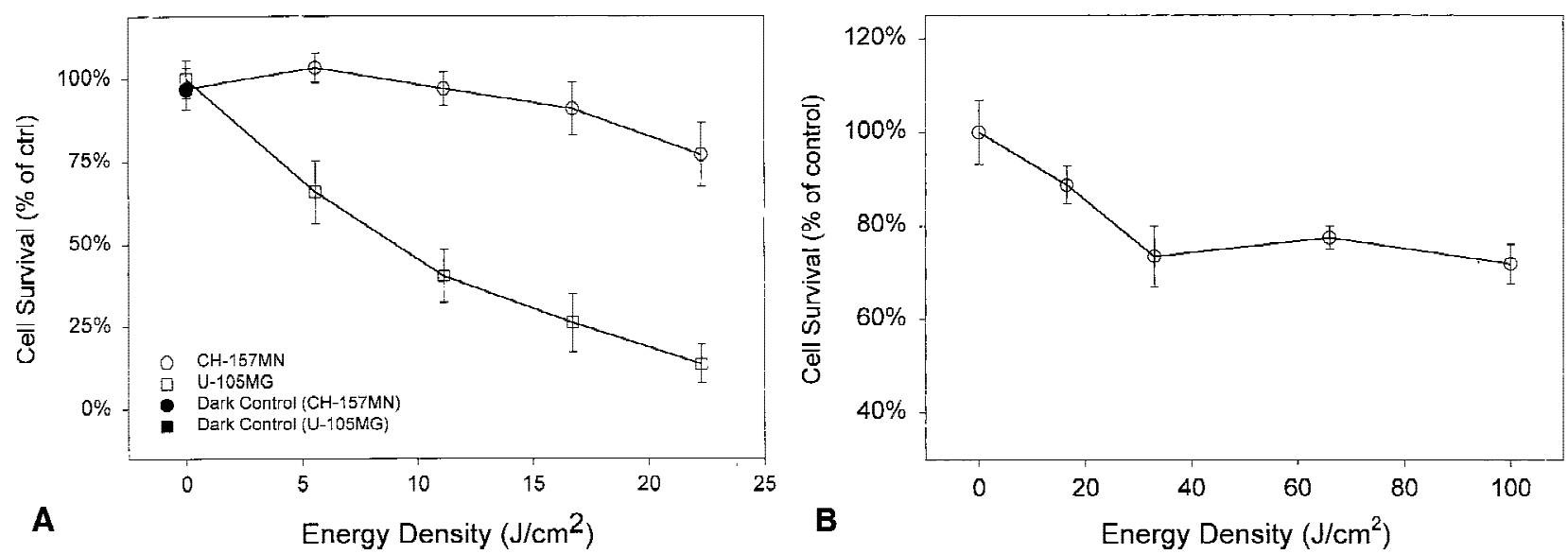

Fig. 3. (A) The CH-157MN meningioma cells were much less susceptible to ALA-PDT than U-105MG glioma cells when ALA $100 \mu \mathrm{g} / \mathrm{ml}$ was used. MTT assay was performed 24 hours after PDT. Percentage cell survival was calculated from the absorbance of test group divided by absorbance of control group. Each data point represents the mean \pm standard deviation of quintuplicate cultures. (B) In CH-157MN meningioma cells, no further increase of cytotoxicity could be obtained when light density was greater than $35 \mathrm{~J} / \mathrm{cm}^{2}$ (up to $100 \mathrm{~J} / \mathrm{cm}^{2}$ ). The concentration of ALA used was $100 \mu \mathrm{g} / \mathrm{ml}$.

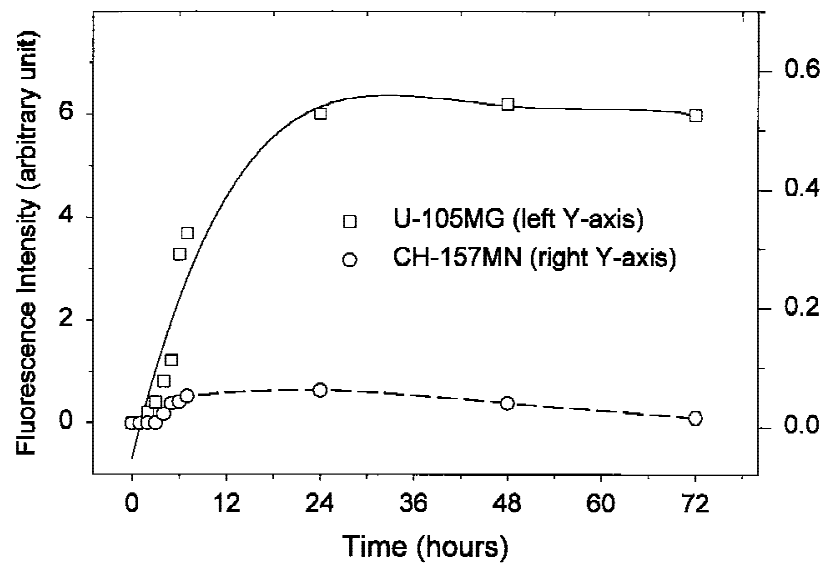

Fig. 4. Cells were incubated with ALA at a concentration of $100 \mu \mathrm{g} / \mathrm{ml}$. At various times after incubation, PpIX was extracted with DMSO. The fluorescence intensity of PpIX was detected at $637 \mathrm{~nm}$. The measurement conditions were kept the same for both U-105MG and CH-157MN cells. The fluorescence intensity of PpIX in U-105MG glioma cells was much higher than that in $\mathrm{CH}-157 \mathrm{MN}$ meningioma cells. Note the different $\mathrm{Y}$-axis scales for U-105MG cells (left Y-axis) and CH-157MN (right Y-axis).

tological diagnosis and relief of raised intracranial pressure. Since these tumors rarely have a distinct boundary, it is difficult to discriminate them from surrounding normal brain tissue during operation even under the operating microscope. In fact, tumor cells infiltrate into regions of otherwise normal parenchyma, making it almost impossible to resect these tumors completely without creating new neurological deficits [12]. Consequently, the current strategies are to resect the tumor as much as possible without inducing fur- ther neurological deficit of the patient, and then follow with adjuvant therapies such as radiation therapy, interstitial brachytherapy, and chemotherapy. In our previous study, we demonstrated that the ratio of the amount of HPD between glioma and brain was 6.1 , whereas the ratio between brain adjacent to tumor and brain was 3.9 [13]. In this study, we showed that ALA-PDT could effectively kill glioma cells in vitro. Therefore, PDT may be an effective and promising adjuvant therapy to treat the residual tumor cells in the tumor bed after the gross resection of malignant gliomas. In comparison with other adjuvant therapies, resistance to PDT has not been encountered during the treatment. This is a distinct advantage of PDT over other anticancer modalities [2]. Furthermore, there is no long-term morbidity of PDT to restrict its repeated applications.

\section{Differential Susceptibility to PDT Between Meningioma and Glioma Cells}

In this study, we demonstrated that the susceptibility of $\mathrm{CH}-157 \mathrm{MN}$ meningioma cells to ALA-PDT was much lower than that of U-105MG glioma cells (Fig. 3). The cause of the different effects is still not clear. Selective uptake or release of ALA may be a possible mechanism, or it might be due to the differences in metabolism of ALA. Unlike other photosensitizer, ALA has to be metabolized by the cells into PpIX before becoming a photosensitizing agent [5]. It seems possible that U-105MG glioma cells might have an increased uptake of ALA, an increased synthesis of 

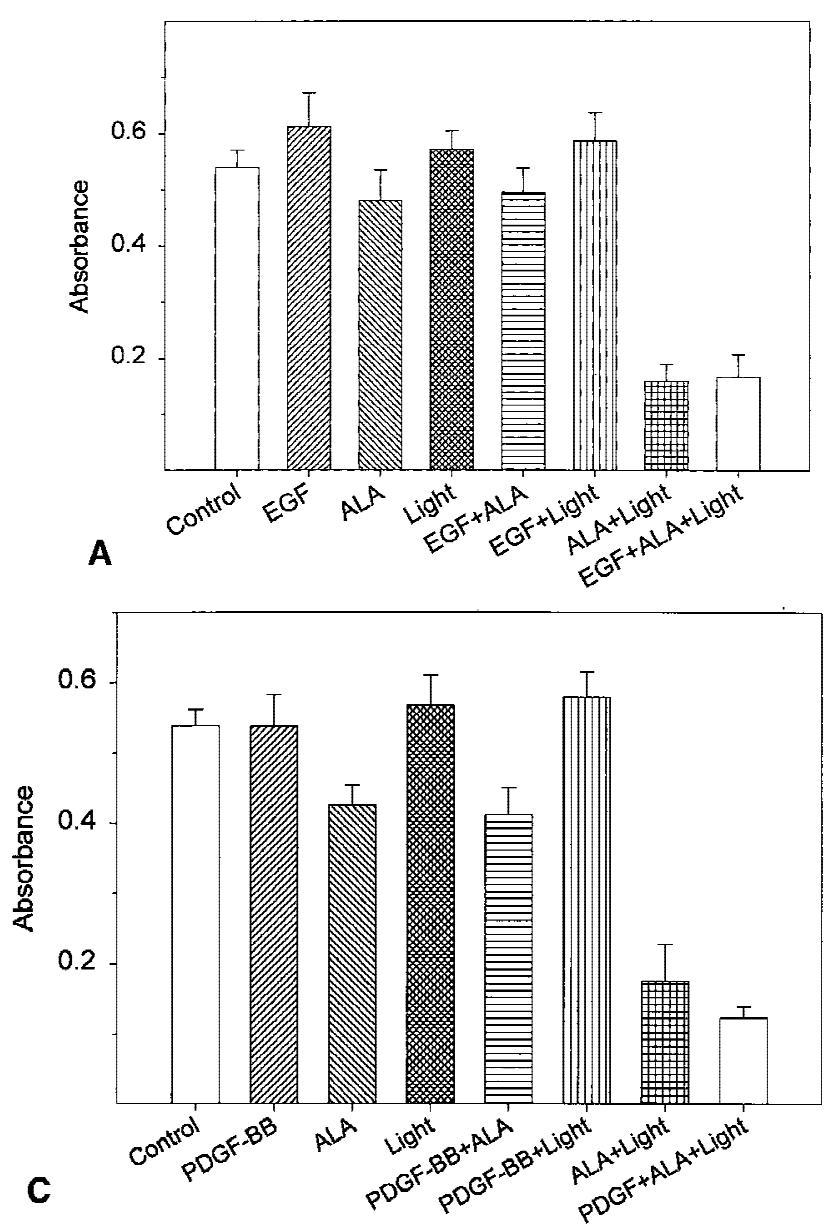

PpIX, or a decreased efflux of PpIX, or a combination of the above, and therefore respond more pronouncedly to PDT than $\mathrm{CH}-157 \mathrm{MN}$ meningioma cells. Rebeiz et al. have suggested that cells with a rapid turnover produce more PpIX [14]. In this study, we found that the concentration of PpIX in U-105MG cells was much higher than that in CH-157MN cells (Fig. 4), and this might explain why U-105MG cells responded more pronouncedly to PDT than $\mathrm{CH}-157 \mathrm{MN}$ cells. It is also possible that $\mathrm{CH}-157 \mathrm{MN}$ meningioma cells might inherently possess a greater tolerance to PDT like some other cell lines reported by Sharkey et al. or Luna et al. $[15,16]$.

In animal and human studies, ALA-induced PpIX fluorescence accumulates primarily in the epithelial surfaces, but not in the major tissues of mesodermal origin (such as muscle, connective tissue, cartilage, blood, and bone marrow) [3]. This tissue selectivity may result from different capacities of heme production, but may also relate to the different feedback control mechanisms in

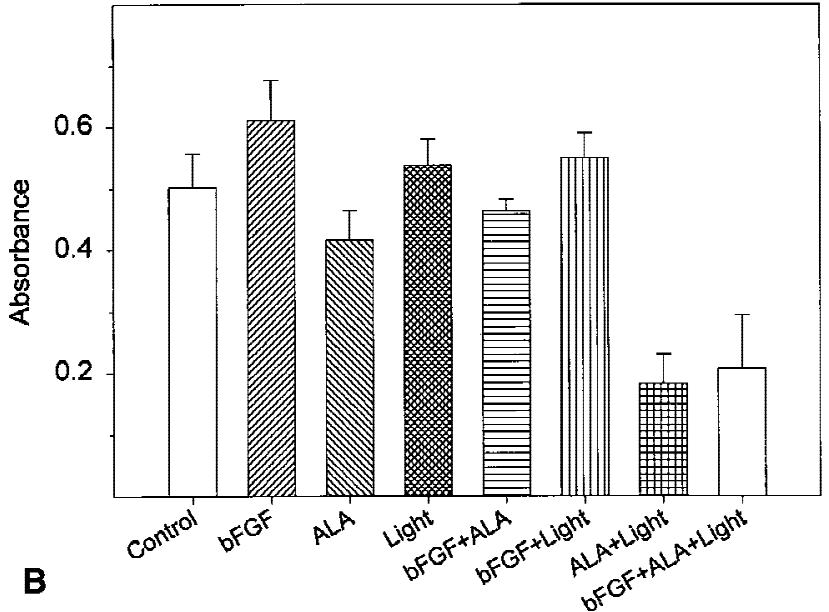

Fig. 5. The U-105MG glioma cells were cultured in serum free medium for 24 hours. Growth factor (EGF, bFGF, or PDGF$\mathrm{BB})$ was added to achieve a final concentration of $50 \mathrm{ng} / \mathrm{ml}$. Thirty minutes later, the cells were incubated with ALA (100 $\mu \mathrm{g} / \mathrm{ml}$ ) for 24 hours, washed, and irradiated with light (11 $\mathrm{J} / \mathrm{cm}^{2}$ ). MTT assay was performed 24 hours after light irradiation. EGF (A), bFGF (B), or PDGF-BB (C) did not have any effects on the susceptibility of U-105MG cells to ALA-PDT. A three way ANOVA was used to analyze the data and all pairwise multiple comparison procedures (Bonferroni t-test) were performed as the post hoc test. Each data point represents the mean \pm standard deviation of nonuple cultures.

different types of cells. Meningiomas are neoplasms derived from the arachnoidal cap cells (cells forming the outer lining of the arachnoid membrane). Whether the arachnoidal cap cell is derived from the neural crest or the mesoderm is itself still controversial [17]. Rubinstein includes all meningiomas under mesodermal tumors [18]. In this study, we found that ALA-induced PpIX fluorescence in $\mathrm{CH}-157 \mathrm{MN}$ meningioma cells is very low, consistent with the findings of Kennedy et al. that PpIX is not accumulated in tissues of mesodermal origin [3]. Steichen et al. reported that malignant astrocytoma cells showed preferential uptake and retention of tetraphenylphosphonium (a photosensitizer) relative to meningioma cells and normal controls [19]. In this study, we showed that the intracellular concentration of PpIX was much higher in glioma cells than in meningioma cells. These findings suggest that malignant gliomas are potentially ideal targets for PDT whereas meningiomas are not. Meningiomas are usually benign, well-circumscribed 


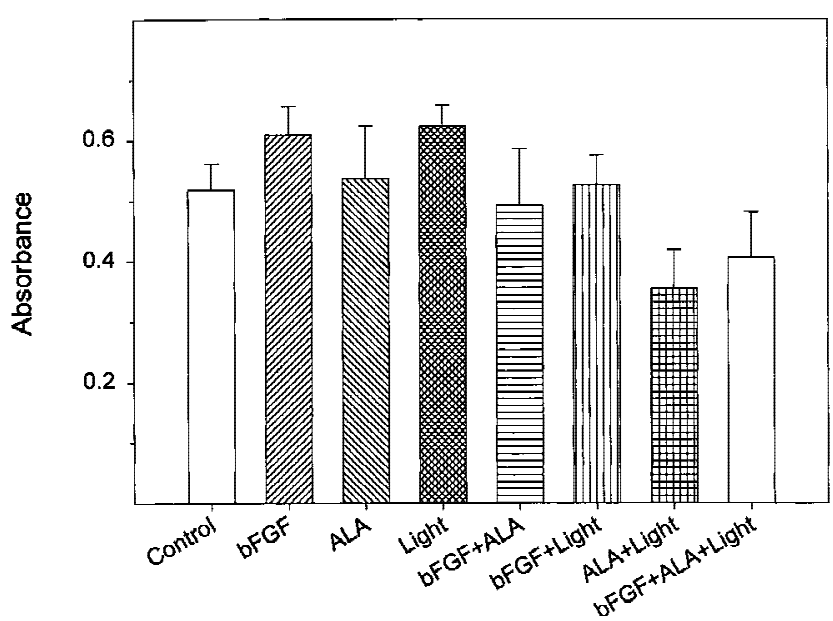

Fig. 6. The $\mathrm{CH}-157 \mathrm{MN}$ meningioma cells were cultured in serum free medium for 24 hours. Basic FGF was add to achieve a final concentration of $50 \mathrm{ng} / \mathrm{ml}$. 30 minutes later, the cells were incubated with ALA $(100 \mu \mathrm{g} / \mathrm{ml})$ for 24 hours, washed, and irradiated with light $\left(30 \mathrm{~J} / \mathrm{cm}^{2}\right)$. MTT assay was performed 24 hours after light irradiation. Basic bFGF did not have any effects on the susceptibility of $\mathrm{CH}-157 \mathrm{MN}$ cells to ALA-PDT. A Three Way ANOVA was used to analyze the data and all pairwise multiple comparison procedures (Bonferroni t-test) were performed as the post hoc test. Each data point represents the mean \pm standard deviation of nonuple cultures.

masses that indent rather than invade the brain or spinal cord. Total excision is the treatment of first choice for a meningioma. PDT might not be useful for treating these tumors. However, the poor effect of ALA-PDT on CH-157MN meningioma cells in vitro can not totally exclude the usefulness of ALA-PDT in vivo, since PDT can cause cell death not only by direct disruption of the cells, but also by damage to the tumor vasculature leading to secondary tumor cell death [2]. Further studies are needed before making the conclusion that ALA-PDT is useless in treating meningiomas.

\section{Effects of Growth Factors on ALA-PDT}

Aberrant expression of proto-oncogenes encoding growth factors or their receptors has been found in human astrocytomas and meningiomas, including $c$-sis/PDGF-B and c-erb B/EGF-receptor [20-23]. Since these receptor gene products control cell growth and differentiation, it is possible that a structurally altered or deregulated receptor could participate in neoplastic transformation and growth. Glioblastoma multiforme, the most frequent malignant brain tumor in humans, has been shown to express PDGF receptors [20] or overexpress EGF receptors constitutively [21].

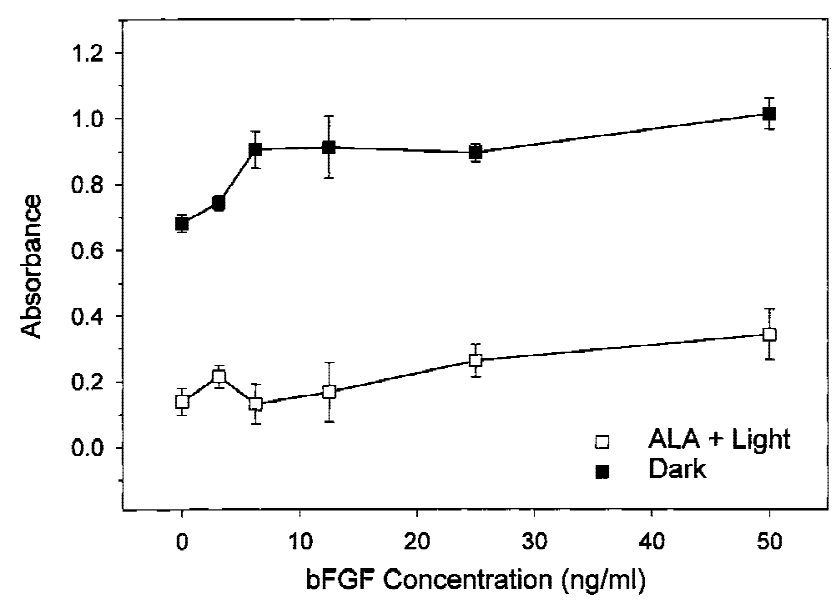

Fig. 7. The CH-157MN meningioma cells were cultured in serum free medium for 24 hours. Various amounts of bFGF were added to achieve a final concentration from $3.125 \mathrm{ng} / \mathrm{ml}$ to $50 \mathrm{ng} / \mathrm{ml}$. Thirty minutes later, the cells were incubated with ALA $(100 \mu \mathrm{g} / \mathrm{ml})$ for 24 hours, washed, and irradiated with light $\left(30 \mathrm{~J} / \mathrm{cm}^{2}\right)$. In the dark control group, the cells were incubated with various concentrations of $\mathrm{bFGF}$, but neither light nor ALA was given. MTT assay was performed 24 hours after light irradiation. The two curves in the figure were nearly parallel to each other. There were no significant differences of cell survival rates (PDT group divided by dark control group at each concentration of bFGF) between groups of differential concentration of bFGF (ANOVA, $P>0.05$ ).

Each of these growth factors has been shown to stimulate the proliferation of PDGF or EGF receptor-positive malignant glioma cells [24-27]. Transforming growth factor- $\alpha$ (TGF- $\alpha$, a peptide factor homologous to EGF), PDGF, or bFGF can also be secreted by glioma cells [26-28], all of which can stimulate the proliferation of EGF, PDGF, or bFGF receptor-positive malignant cells. Thus, glioma-secreted cytokines probably establish an autocrine mechanism in tumor growth.

Meningioma is the most frequent benign brain tumor in humans. Unlike glioblastomas, meningiomas have a much better clinical course. Weisman et al. have shown that both EGF and FGF stimulated cell proliferation in human meningioma cultures, and a combination of PDGF and EGF synergistically stimulated DNA synthesis to near maximal levels [29]. These findings suggest that an autocrine loop that involves one or both of these growth factors is present in meningioma too.

Therefore, the growth of glioma and meningioma cells is up-regulated by abnormal growth signals. It is interesting to know if the high growth signals in tumor cells could affect the susceptibility of the cells to PDT. If this is the case, PDT would be more effective in killing rapid pro- 
liferating tumor cells, and would lead to a better selectivity in treating a tumor infiltrating the surround normal tissue, for example, a glioma. In this study, however, we were not able to demonstrate either a stimulating or an inhibiting effect of growth factors (EGF, bFGF, and PDGF-BB) on susceptibility of cells to ALA-PDT (Figs. 5-7). These results may indicate that the growth factors do not enhance PDT-induced cytotoxicity. It is also possible that the growth signals in glioma cells may be already very high that the extra growth factors added could not induce a significant effect. In this study, we starved the cells for 24 hours by cultivating the cells in serum free medium before adding growth factors. EGF and bFGF did show a stimulatory effect on the growth of glioma cells and meningioma cells as shown in Figures 5-7. Though the effect was not very prominent, it was statistically significant.

The U-105MG glioma cells were so sensitive to ALA-PDT that it might be difficult to demonstrate an enhancing effect of growth factors on the efficiency of ALA-PDT in U-105MG. However, we had tried several different experimental conditions, such as decreasing dosage of ALA, decreasing dosage of light irradiation, but we still could not demonstrate any enhancing effect. On the contrary, we also could not demonstrate any effect of growth factors on the susceptibility of $\mathrm{CH}$ $157 \mathrm{MN}$ meningioma cells to ALA-PDT despite that meningiomas cells were quite resistant to ALA-PDT. Consequently, the growth factors (EGF, bFGF, and PDGF-BB) seemed to have neither a stimulatory nor an inhibitory effect on the efficiency of ALA-PDT for U-105MG glioma cells or $\mathrm{CH}-157 \mathrm{MN}$ meningioma cells.

In summary, both U-105MG glioblastoma cell line and CH-157MN meningioma cell line accumulated ALA-induced PpIX and demonstrated good and moderate sensitivity to ALA-PDT respectively. ALA-PDT was more effective in killing U-105MG glioma cells than $\mathrm{CH}-157 \mathrm{MN}$ meningioma cells. The differential susceptibility was likely due to the differential accumulation of PpIX in these cells. Growth factors, such as EGF, bFGF, or PDGF-BB did not have a stimulatory or inhibitory effect on the efficiency of ALA-PDT for these two cell lines.

\section{ACKNOWLEDGMENT}

We thank Dr. Yancey Gillespie (University of Alabama at Birmingham, Birmingham, AL) for providing meningioma cell line $\mathrm{CH}-157 \mathrm{MN}$.

\section{REFERENCES}

1. Dougherty TJ. Photodynamic therapy. Photochem Photobiol 1993;58:895-900.

2. Fisher AM, Murphree AL, Gomer CJ. Clinical and preclinical photodynamic therapy. Lasers Surg Med 1995; $17: 2-31$.

3. Kennedy JC, Pottier RH. Endogenous protoporphyrin IX, a clinically useful photosensitizer for photodynamic therapy. J Photochem Photobiol B 1992;14:275-292.

4. Messmann H, Mlkvy P, Buonaccorsi G, Davies CL, MacRobert AJ, Bown SG. Enhancement of photodynamic therapy with 5 -aminolaevulinic acid-induced porphyrin photosensitisation in normal rat colon by threshold and light fractionation studies. Br J Cancer 1995;72:589-594.

5. Kennedy JC, Pottier RH, Pross DC. Photodynamic therapy with endogenous protoporphyrin IX: basic principles and present clinical experience. J Photochem Photobiol B 1990;6:143-148.

6. Loh CS, MacRobert AJ, Bedwell J, Regula J, Krasner N, Bown SG. Oral versus intravenous administration of 5 -aminolaevulinic acid for photodynamic therapy. Br J Cancer 1993;68:41-51.

7. Cairnduff F, Stringer MR, Hudson EJ, Ash DV, Brown SB. Superficial photodynamic therapy with topical 5 -aminolaevulinic acid for superficial primary and secondary skin cancer. Br J Cancer 1994;69:605-608.

8. Bigner DD, Bigner SH, Ponten J, Westermark B, Mahaley MS, Ruoslahti E, Herschman H, Eng LF, Wikstrand CJ. Heterogeneity of Genotypic and phenotypic characteristics of fifteen permanent cell lines derived from human gliomas. J Neuropathol Exp Neurol 1981;40:201229.

9. Wyld L, Burn JL, Reed MW, Brown NJ. Factors affecting aminolaevulinic acid-induced generation of protoporphyrin IX. Br J Cancer 1997;76:705-712.

10. Schoenfeld N, Epstein O, Lahav M, Mamet R, Shaklai M, Atsmon A. The heme biosynthetic pathway in lymphocytes of patients with malignant lymphoproliferative disorders. Cancer Lett 1988;43:43-48.

11. el-Sharabasy MM, el-Waseef AM, Hafez MM, Salim SA. Porphyrin metabolism in some malignant diseases. Br J Cancer 1992;65:409-412.

12. Ammirati M, Vick N, Liao YL, Ciric I, Mikhael M. Effect of the extent of surgical resection on survival and quality of life in patients with supratentorial glioblastomas and anaplastic astrocytomas. Neurosurgery 1987;21:201206.

13. Tsai JC, Kao MC, Hsiao YY. Fluorospectral study of the rat brain and glioma in vivo. Lasers Surg Med 1993;13: 321-331.

14. Rebeiz N, Rebeiz CC, Arkins S, Kelley KW, Rebeiz CA. Photodestruction of tumor cells by induction of endogenous accumulation of protoporphyrin IX: enhancement by 1,10-phenanthroline. Photochem Photobiol 1992;55: 431-435.

15. Sharkey SM, Wilson BC, Moorehead R, Singh G. Mitochondrial alterations in photodynamic therapy-resistant cells. Cancer Res 1993;53:4994-4999.

16. Luna MC, Ferrario A, Rucker N, Gomer CJ. Decreased expression and function of alpha-2 macroglobulin receptor/low density lipoprotein receptor-related protein in photodynamic therapy-resistant mouse tumor cells. Cancer Res 1995;55:1820-1823.

17. Stanton CA, Challa VR. Meningiomas: Pathology. In: 
Wilkins RH, Rengachary SS, editors. Neurosurgery. 2nd ed. New York: McGraw-Hill, 1996. p 843-854.

18. Challa VR, Markesbery WR. Meningiomas. In: Wilkins RH, Rengachary SS, editors. Neurosurgery. 1st ed. New York: McGraw-Hill, 1985. p 613-622.

19. Steichen JD, Weiss MJ, Elmaleh DR, Martuza RL. Enhanced in vitro uptake and retention of $3 \mathrm{H}$ tetraphenylphosphonium by nervous system tumor cells. J Neurosurg 1991;74:116-122.

20. Nister M, Heldin CH, Westermark B. Clonal variation in the production of a platelet-derived growth factor-like protein and expression of corresponding receptors in a human malignant glioma. Cancer Res 1986;46:332-340.

21. Maruno M, Kovach JS, Kelly PJ, Yanagihara T. Transforming growth factor-alpha, epidermal growth factor receptor, and proliferating potential in benign and malignant gliomas. J Neurosurg 1991;75:97-102.

22. Maxwell M, Galanopoulos T, Hedley-Whyte ET, Black PM, Antoniades HN. Human meningiomas co-express platelet-derived growth factor (PDGF) and PDGFreceptor genes and their protein products. Int J Cancer 1990;46:16-21.

23. Weisman AS, Raguet SS, Kelly PA. Characterization of the epidermal growth factor receptor in human meningioma. Cancer Res 1987;47:2172-2176.
24. Lund-Johansen M, Forsberg K, Bjerkvig R, Laerum OD. Effects of growth factors on a human glioma cell line during invasion into rat brain aggregates in culture. Acta Neuropathol 1992;84:190-197.

25. Pollack IF, Randall MS, Kristofik MP, Kelly RH, Selker RG, Vertosick F, Jr. Response of low-passage human malignant gliomas in vitro to stimulation and selective inhibition of growth factor-mediated pathways. J Neurosurg 1991;75:284-293.

26. Sporn MB, Todaro GJ. Autocrine secretion and malignant transformation of cells. N Engl J Med 1980;303: 878-880.

27. Takahashi JA, Fukumoto M, Igarashi K, Oda Y, Kikuchi H, Hatanaka M. Correlation of basic fibroblast growth factor expression levels with the degree of malignancy and vascularity in human gliomas. J Neurosurg 1992;76: 792-798.

28. Westermark B, Heldin CH. Platelet-derived growth factor. Structure, function and implications in normal and malignant cell growth. Acta Oncologica 1993;32:101105.

29. Weisman AS, Villemure JG, Kelly PA. Regulation of DNA synthesis and growth of cells derived from primary human meningiomas. Cancer Res 1986;46:2545-2550. 